\title{
Nadbiskup Stepinac o sibinjskim žrtvama i mise zadušnice za njih u crkvama Zagrebačke nadbiskupije u veljači i ožujku 1935. godine
}

\author{
MATO ARTUKOVIĆ* \\ • https://doi.org/10.31823/d.26.4.3 • \\ UDK: 27-58-722.51-058.6 Stepinac, A. (497.5 Sibinj) • Izvorni znanstveni rad \\ Primljeno: 17. siječnja 2018. Prihvaćeno: 6. prosinca 2018.
}

Sažetak: U radu se predstavljaju pogledi nadbiskupa Alojzija Stepinca o sibinjskim žrtvama u vrijeme predizborne kampanje 1935. godine. Vlasti su za dogadaje u kojima je ubijeno 15 hrvatskih seljaka optužile same te seljake $i$ župnika iz Podcrkavlja Mihovila Praskića. Nadbiskup Stepinac jasno je označio bitan uzrok svega: neravnopravnost naroda i samovolju žandara. Dopustio je služenje mise zadušnice za ubijene selja$k e$ što je ogorčilo nositelje vlasti. Potaknuti zagrebačkim primjerom, spontano su i u drugim mjestima Nadbiskupije služene zadušnice za žrtve zločina za koji nitko nije odgovarao.

* Dr. sc. Mato Artuković, Hrvatski institut za povijest - Podružnica za povijest Slavonije, Srijema i Baranje, Ante Starčevića 8, 35000 Slavonski Brod, Hrvatska, artukovic. mato@gmail.com

Ključne riječi: Sibinjske žrtve 1935. godine, nadbiskup Alojzije Stepinac i sibinjske žrtve, mise zadušnice u Zagrebu $i$ drugim župama Zagrebačke nadbiskupije, pjesme i poklici na zadušnicama.

\section{Uvod}

Krajem prosinca 1934. godine Bogoljub Jevtić postao je predsjednik Vlade Kraljevine Jugoslavije. Prije toga bio je ministar inozemnih poslova i u toj funkciji pratio je kralja Aleksandra na putu u Marseilles. Bio je zaogrnut aureolom $\gg$ čuvara poslednjih kraljevih reči $\ll, ~ \gg$ amaneta kralja Aleksandra «: $\gg$ Čuvajte Jugoslaviju «, što mu ih je kralj tobože rekao prije nego je umro kao žrtva atentata u Marseillesu. ${ }^{1}$

${ }^{1}$ Tvorac tih tobože kraljevih posljednjih riječi jest Ivan Vanja Subotić, unuk poznatoga Jovana Subotića, jednoga od zagrebačkih septemvira. Više o tome: B. RADICA, Ne A. Karađorđević - nego I. Subotić: 'Čuvajte Jugoslaviju', u: Hrvatska revija 3(1973.)91, 453-454. 
Novi predsjednik Vlade htio je svojem kabinetu pribaviti što veću potporu u Narodnoj skupštini. Zato je početkom veljače 1935. godine raspisao izbore odredivši ih za 5. svibnja. Odmah nakon raspisivanja izbora stvorena je Udružena opozicija, koju su sačinjavale, doduše, zabranjene, ali nikada ugašene predšestosiječanjske stranke: Seljačko-demokratska koalicija (HSS i SDS), Srpska zemljoradnička stranka Jovana Jovanovića, Demokratska stranka Ljube Davidovića i Jugoslavenska muslimanska organizacija Mehmeda Spahe. ${ }^{2}$ Na prijedlog vođa srpske oporbe za nositelja zemaljske kandidatske liste izabran je dr. Vladko Maček, predsjednik HSS i SDK, koji je tih dana pušten iz zatvora u Mitrovici. Mačekov pristanak da se stavi na čelo oporbe jako je iznenadio, pa i uplašio nositelje vlasti. Vlada je zabranila da novine pišu o samoj mogućnosti pojave neke opozicije sve dok nije sud odobrio kandidaturu Vladka Mačeka. Jevtić je htio, među ostalim novostima, pokazati da njegova Vlada prekida praksu monopola na patriotizam. No upravo ti izbori i kampanja kojom su vođeni pokazali su da je to bila samo obična obmana. Kao i sve vlade prije nje, i ta je vodila unitarističku i centralističku politiku, koja je favorizirala srpstvo pod vidom jugoslavenskoga unitarizma i to krajnje nedemokratskim metodama. Svako isticanje nacionalnih vrijednosti drugih nacija označeno je kao separatizam. Osobito se oštro postupalo prema isticanju hrvatskih nacionalnih osjećaja, koji su ocijenjeni kao »plemenski $\ll \mathrm{i} \gg$ predelni $\ll$, odnosno separatistički. U ime krilatice »jednoga troimenog naroda « počinjeni su teški zločini. Od samoga dana objave izbora Vlada se svim državnim aparatom i svim propagandnim sredstvima koristila za vlastitu promidžbu, a onemogućila je bilo kakvu aktivnost opozicije. Sam Bogoljub Jevtić izbacio je geslo pod kojim je Vlada vodila izbore: »Tko glasa za Mačeka, glasa za Janka Pustu! « Taj ustaški logor u Mađarskoj bio je sinonim separatizma, pa je takva formulacija temeljnoga predizbornoga slogana još više zatrovala atmosferu u kojoj se odvijala izborna kampanja i provodili izbori. ${ }^{3}$

Od samoga početka predizborne kampanje nije se prezalo ni od brutalnih nasrtaja na pristalice opozicije. U suzbijanju bilo kakvoga iskazivanja hrvatskoga nacionalnoga osjećaja oružništvo je ne samo masovno uhićivalo i batinalo ljude nego je bilo spremno i na krvoproliće. Za to je ilustrativan primjer ono što se događalo u selima brodskoga kotara. Zatvaranja i batinanja seljaka izazvala su masovna gibanja cijelih sela, koja su se pokrenula da oslobode uhićene. Tako su se dignula sela u okolici Slavonskoga Broda: Jakačina Mala, Grižići, Gornji Andrijevci, Slobodnica, Podcrkavlje, Podvinje, Sibinj, Ruščica, Gornja i Donja Vrba. Žandari su ubili u Sibinju devet seljaka iz odvoračkih sela, a kod groblja u Slavonskom Brodu još šest seljaka

\footnotetext{
${ }^{2}$ F. TUĐMAN, Hrvatska u monarhističkoj Jugoslaviji 1918. - 1941., II, Zagreb, 1993., 148.

${ }^{3}$ Isto, 149.
} 
iz Vrbe i Ruščice. ${ }^{4}$ Prema izjavama seljaka žandari su, bez mnogo razmišljanja, pucali s namjerom da ubiju. Prema svjedočenju žandara njihovi životi bili su ugroženi, pa su pucali nakon što su seljaci zapucali na njih. Zanimljivo je da su seljaci optuženi da su oba puta prvi pucali, a da nitko od žandara nije poginuo. Mnogi seljaci su inače bili lovci, pa im oružje nije bilo strano. Seljaci su tvrdili da vatreno oružje nisu ni imali. Liječnički nalazi koji su sačuvani potvrđuju da su žandari ranjeni isključivo udarcima tupih predmeta, poput dasaka ili kolaca. ${ }^{5}$ Za te događaje i žrtve vlasti su optužile Mihovila Praskića, župnika iz Podcrkavlja. Treba svakako istaknuti i ulogu četnika u tim događajima. Praskić je 17. veljače nenajavljeno sudjelovao na proslavi Papinoga dana u Sibinju, gdje je poslije mise pozvao narod da glasuje na izborima za Mačeka. Potom je s kolonom od deset kola seljaka otišao u Oriovac, gdje je u crkvenom dvorištu okupljene ljude ponovno pozvao da glasuju za listu dr. Vladka Mačeka na izborima 5. svibnja. Na putu i na povratku klicalo se slobodnoj Hrvatskoj, Mačeku i $\gg$ dolje četnici«. Jedan od sibinjskih četnika, općinski pisar Marko Matošević, zapucao je na kolonu i pobjegao kad su ovi krenuli prema njemu. Upravo optužbe četnika da se klicalo u Oriovcu slobodnoj Hrvatskoj i »dolje Jugoslavija « izazvale su uhićenja, a onda i masovne prosvjede seljaka i njihove zahtjeve da se uhićeni puste jer su bili u zatvoru mučeni. ${ }^{6} \mathrm{Uz}$ to su žandari počinili krvoprolića za vrijeme predizborne kampanje i u Primoštenu u Dalmaciji, kraj Klanca u Lici, u Selnici u Hrvatskom zagorju. ${ }^{7}$

U svojim Memoarima Vladko Maček je o tim događajima zapisao: »Moram spomenuti da je odmah u početku izborne borbe došlo do sukoba između seljaka sela Sibinj i žandarmerije. Rezultat je bio devet mrtvih i nekoliko desetaka ranjenih se-

\footnotetext{
${ }^{4} \mathrm{O}$ tom zločinu režima monarhističke Jugoslavije u veljači 1935. godine sada već postoji priličan broj radova ili kraćih zabilješki u opširnijim sintezama. Više o sibinjskim događajima najtemeljitiji rad: D. JOVIĆ, Pobuna seljaka u okolici Slav. Broda februara 1935. godine, u: Z. KRNIĆ (ur.), Zbornik Historijskog instituta Slavonije, IX, Slavonski Brod, 1972., 157-209.; F. TUĐMAN, Hrvatska u monarhističkoj Jugoslaviji, II, 146-148.; usp. također i B. JANJATOVIĆ, Politički teror u Hrvatskoj 1918. - 1935., Zagreb, 2002., 92-95.; T. STOJKOV, Opozicija u vreme šestojanuarske diktature 1929-1935., Beograd, 1969., 292.; usp. i drukčije mišljenje u novijoj srpskoj historiografiji: I. DOBRIVOJEVIĆ, Državna represija u doba diktature kralja Aleksandra (1929-1935), Beograd, 2006., 198-201. Bibliografiju o Sibinjskim žrtvama vidi u: M. ARTUKOVIĆ, Sibinjske žrtve u povijesnoj literaturi i publicistici, u: Dani dr. Franje Tudmana. Hrvati kroz stoljeća. Zbornik radova, 7/IX, Veliko Trgovišće, 2017., 105-126.

${ }^{5}$ N. TRAVAREVIĆ, Padoše nevini, padoše od sile. Monografija povodom 80. obljetnice Sibinjskih žrtava, Sibinj, 2015., 69-70.

${ }^{6} \mathrm{Na}$ značenje četnika u događanjima u Sibinju upozorio je Z. DIZDAR, Osnivanje i djelatnost četničkih udruženja na području slavonskobrodskog kotara u razdoblju Kraljevine Jugoslavije, u: Scrinia Slavonica 2(2002.), 91-95. Prva je o važnosti četnika za zbivanja u ovom području pisala F. JELIĆ-BUTIĆ, Iz povijesti četničkog pokreta u Hrvatskoj između dva rata (1934. - 1936.), u: Radovi 21(1988.) 1, 145-232.

${ }^{7}$ F. TUĐMAN, Hrvatska u monarhističkoj Jugoslaviji, II, 148.
} 
ljaka. Izgleda da se na taj način mislilo narod uplašiti i slomiti mu opozicijski izborni elan. Dogodilo se protivno, jer je taj žalosni događaj potaknuo ljude na još žešću borbu. $\ll^{8}$ Komentirajući Sibinjske žrtve, američki vojni ataše F. L. Whitley opisao je stanje državne represije ovako: »Policijske mjere u Jugoslaviji su jednostavne, izravne i teške. Mauserov karabin na ramenu oružnika podsjeća stanovništvo da nemiri i demonstracije protiv režima ne će biti tolerirani. Izvješća o onima koji se opiru, zatvaraju se kratkom bilješkom: 'Umro ili smrtno ranjen pri opiranju uhićenju.' I tu sve završava. Nema problematičnih istraga ili mjera zbog pogrešnog utamničenja, a niti prikladne Austro-Ugarske za okriviti. ${ }^{9}$

U pismu Srbima seljacima, koje se kao letak trebalo širiti Likom, opozicijski kandidat Sava Kosanović opisao je tragične posljedice državnoga terora, koji su provodili žandari i četnici. Revni ban Kostrenčićc ${ }^{10}$ uspio je zaplijeniti to pismo. U njemu

${ }^{8}$ V. MAČEK, Memoari, Zagreb, 2003., 163.

${ }^{9} \mathrm{H}$. ČAPO, Kraljevina čuvara. Represivni aparat monarhističke Jugoslavije na području hrvatskih zemalja (1918. - 1941.), Zagreb, 2015., 106.

${ }^{10}$ Marko Kostrenčić (1884. - 1976.), pravni povjesničar i političar. Klasičnu gimnaziju završio je u Zagrebu, gdje je diplomirao i doktorirao na Pravnom fakultetu. Na preporuku Tadije Smičiklasa proučavao je pravnu povijest slavenskih naroda na sveučilištima u Pragu, Varšavi, Krakovu, Lavovu i Beču. Godine 1912. bio je izabran za docenta na Pravnom fakultetu na novoosnovanoj katedri za hrvatsku pravnu povijest na kojoj je predavao do 1931. Te je godine postao ministar socijalne politike i narodnog zdravlja u vladi generala Pere Živkovića. U prosincu 1934. godine imenovan je banom Savske banovine, na toj je dužnosti ostao do umirovljenja u travnju 1836. U vrijeme kad se bavio politikom, predavao je honorarno na Pravnom fakultetu. Zbog izrazito jugoslavenske političke orijentacije bio je zatočen u Staroj Gradiški 1941. - 1942. Nakon rata je reaktiviran kao profesor na Pravnom fakultetu gdje je predavao do umirovljenja 1955. godine kao redovni profesor. Sastavio je sveučilišne udžbenike Hrvatska pravna povijest (1919., 1923.), Nacrt historije hrvatske države i hrvatskog prava (1956.), pisao je o povijesti Pravnoga fakulteta, Dušanovu zakoniku, komunalnim pravima i organizacijskoj strukturi dalmatinskih gradova. Priloge je objavljivao u Mjesečniku Pravničkog društva, Savremeniku, Pravnom savjetniku, Narodnoj starini, Ljetopisu JAZU, Radu JAZU, Novoj Evropi, Obzoru, Zborniku Pravnogfakulteta, Historijskom zborniku i drugim časopisima i novinama. Bio je rektor zagrebačkoga sveučilišta 1949. - 1950., redoviti član JAZU od 1921., glavni tajnik 1951. - 1957. i potpredsjednik JAZU 1957. - 1958., suosnivač HAŠK-a (1903.), za koji je igrao na prvoj javnoj utakmici u Zagrebu. Jedan je od prvih natjecatelja i učitelja mačevanja: Hrvatski biografski leksikon, VII, Zagreb, 2009., 698-699. Kostrenčić je jedan od tipičnih predstavnika jugoslavenske unitarističke ideologije. Obarao se na kult Zrinskoga i Frankopana, kao simbola hrvatske nacionalne borbe koji su zagovarali pravaši. Kao jedan od urednika unitarističkoga lista Nova Evropa zalagao se za »narodno jedinstvo «»jednog troimenog naroda «, za $\gg$ otvoreno jugoslavenstvo «, protiv velikosrsptva i velikohrvatstva. »Da je i takvo 'nepristrano' jugoslavenstvo bilo $\mathrm{u}$ interesu hegemonizma, dovoljno je pogledati na koji je način $\mathrm{u}$ istom listu interpretirano ne samo hrvatsko nego i makedonsko pitanje.« F. TUĐMAN, Hrvatska u monarhističkoj Jugoslaviji, I, 326., 398., bilj. 775. U vrijeme kad je ban Savske banovine bio Marko Kostrenčić žandari su u Hrvatskoj učinili neke od najtežih zločina (npr. ubojstva seljaka u Sibinju), koji su ne samo ostali nekažnjeni nego nisu ni istraživani. 
je stajalo: »Od 5. maja 1935. do danas [siječnja 1936.] poginulo je u Hrvatskoj i Dalmaciji devedesetšest ljudi u raznim sukobima od žandarske ili četničke ruke. (...) A sve pod vladavinom proglašene 'ere smirivanja'. Nigde nije saopšteno kako su ispale određene istrage, je li gde krivac kažnjen? Dok su izdavana rešenja da se naplate od sina kuršumi s kojima je zvanično ubijen otac.« U svom obraćanju srpskim seljacima Kosanović se dotaknuo i problematike četničkih odreda koji su provodili ubijanja. O njima je zapisao: »Stoji, međutim, činjenica da postoje četnička udruženja sastavljena iz žandarskih poverenika u narodu. Da su oboružani puškama, revolverima, bombama, da ih je štitila vlast. Neke je vlast morala raspustiti, ali nekima je i posle toga ostavljeno oružje. Ali, samo to, da se kraj policije, žandara i vojske podržavaju na selu još i ovakve čete, govori najporaznije za režim. Naznake naoružavanja četnika iz resursa državnog represivnog aparata otkriva i izvješće kotarskog načelstva Slavonskog Broda da je petorici članova udruženja četnika u Sibinju revolvere 'izdala (...) žandarmerijska stanica u Sibinju na svoju ruku...' ${ }^{11}$ O razmjerima represije u vrijeme Jevtićeve vlade govori i podatak, koji je iznio dr. Branko Kaluđerčić, jedan od ministara u Stojadinovićevoj vladi, da je u nepunih godinu dana Jevtićeva mandata uhićeno oko 50000 ljudi. $^{12}$

\section{O sibinjskom pokolju u Dnevniku nadbiskupa Stepinca}

\subsection{NAPISI IZ NOVINA}

U Dnevniku nadbiskupa Stepinca uz njegove osobne zabilješke o Sibinjskim žrtvama postoje i drugi izvori koji su sastavni dio toga Dnevnika. Ponajprije je to suvremeni tisak, koji je Stepinac lijepio u knjizi. Uglavnom je riječ o jednom listu, zagrebačkim prorežimskim novinama Novosti. Njihova vrijednost je u tome što vjerno odražavaju način kako su vlasti prikazivale uzroke i slijed događanja koji su doveli do ubojstva seljaka. U suvremenom tisku onoga vremena sve o ubojstvu seljaka u Sibinju i kraj groblja u Brodu je ne samo cenzurirano nego je i strogo zabranjeno bilo objaviti bilo što što se ne slaže sa službenim stavom režima. Sve su novine mogle jedino objaviti ono što je o tim događajima govorio ministar unutarnjih poslova Velja Popović. Neke od tih članaka iz Novosti nalazimo u Stepinčevu Dnevniku. U njima se dijabolizira župnik Mihovil Praskić, koji je optužen kao krivac za ubojstvo seljaka. ${ }^{13}$

\footnotetext{
${ }^{11}$ H. ČAPO, Kraljevina čuvara, 280.

${ }^{12}$ F. TUĐMAN, Hrvatska u monarhističkoj Jugoslaviji, II, 151.

${ }^{13}$ U Dnevniku Alojzija Stepinca nalaze se nalijepljeni članci iz Novosti: »Žalosne pojave na selu. Od svećenika zavedeni seljaci navalili na žandarme «; »Zločinački tip seljačkog zavodnika Praskića «, $\gg$ Ko je kriv događajima u Sibinju. Izjava ministra unutrašnjih poslova g. Velimira Popovića «, »Što se dogodilo u Sibinju. Izjava ministra unutarnjih djela g. V. Popovića «, »Portret Mihovila Praskića $\ll$.
} 
Praskić je svakako bio daleko od uzornoga svećenika, ali ga se prikazivalo tako dijaboličnom osobom da sama ta pretjerana revnost u zaštiti žandarske jedinice od svake odgovornosti za ubojstvo seljaka svakako oduzima vjerodostojnost novinama kao izvoru. Uostalom, Praskić je bio oslobođen na Sudu za zaštitu države u Beogradu, kao i kasnije na sudu u Požegi.

\subsection{StepinČEve osobne BILJEŠKe o SibinJSKim ŽRTVAMA}

Stepinac je u svom Dnevniku dosta pozornosti posvetio zbivanjima u Sibinju. Kad su se zločini dogodili, napisao je da »izgleda da ima i $20 \mathrm{mrtvih}$ u selu $\ll$. I nastavlja: »Sudeći po prepisu ove cedulje izgleda da je taj Praskić doista kriv.«U njegovu Dnevniku nalazi se naime nalijepljen jedan prijepis dopisa župnika Praskića datiran 13. veljače 1935. godine. Na tom je prijepisu pisalo: »Dragi predsjedniče! Juče smo izvojevali prvu pobjedu. Oko 700 seljaka došlo je pred općinu u Podcrkavlju i ostali do noći dok nismo nas 16 pušteni. Došlo je žandara 2 auta sa majorom. Oduševljenje i sloga velika. Naprijed sada s Božjom pomoći. Mi osnivamo organizacije Križara. Pozdravlja Vas narod i ja

Mihovil Praskić, svećenik

Molim uručiti Dr. Mačeku!

Podcrkavlje - Brod - Hrvatska.

P.S. Koverta nosi žig: Slavonski Brod 13.II.35. $\ll^{14}$

Očito je Praskić pisao dr. Mačeku o događajima koji su se dogodili tjedan dana ranije. Stepinčev zapis nije sasvim vidljiv. Stranica je oštećena i slova su izblijedjela vjerojatno zbog vlage kojoj je Dnevnik bio izložen. Uz teške napore tekst se možda može pročitati ovako: »Ne odobravam nipošto postupak ovog svećenika (?). [Slijedi jedna nečitka rečenica]. Mi takovih metoda ne trebamo (?). Ali tko će znati pravo stanje stvari? « Stepinac u Dnevniku dalje bilježi: »Međutim ovaj masonski i zločinački list kao što su Novosti kadar je sve napraviti, jer mu je glavno 'kšeft'. On dnevno širi nemoral u našem puku, a pisanje [?] mu je inače onakovo kakovo žele vlasti. Nepoznam Praskića, ali čini se da sve doslovno ipak nije kako to pišu Novosti.« ${ }^{15}$

Za vlasti je slijedio vrlo delikatan događaj. Nakon ubojstva hrvatskih seljaka Hrvatska seljačka stranka tiskala je letak koji je potpisao dr. Vladko Maček imenima ubijenih. Maček obavještava građane Zagreba da su $u$ » borbi sa bezobzirnim režimom poginuli u Sibinju i Brodu « hrvatski seljaci, čije su »žrtve zavile u crno cijeli hrvat-

\footnotetext{
${ }^{14}$ Alojzije Stepinac. Nadbiskup - Koadjutor, I, (dalje: Dnevnik Alojzija Stepinca, I), 120. ${ }^{15}$ Isto.
} 
ski narod «. Svoju solidarnost sa žrtvama trebaju pokazati i građani Zagreba, »pa se umoljava građanstvo, da prisustvuje sv. misi zadušnici, koja će se održati sutra t.j. 23.o. mj. u katedrali u 10 sati prije podne $\ll{ }^{16}$. Letak je tiskan 22 . veljače 1935. godine. Letci su brzo šireni i zabranjivani svuda po Hrvatskoj. Bana Marka Kostrenčića i samoga predsjednika Vlade Bogljuba Jevtića vijest je vrlo uznemirila. Odlučili su reagirati na mjestu za koje su držali da je najutjecajnije. Navečer istoga dana ban je posjetio nadbiskupa Alojzija Stepinca sa zahtjevom da se misa zadušnica zabrani. ${ }^{17}$

Pod nadnevkom 22.2.35. Stepinac piše: $\gg$ Događaji u Brodu čini se da se silno zaoštruju. Danas uvečer u 8 sati došao je iznenada k meni ban dr. Marko Kostrenčić. Začudio sam se dolasku. Ban mi je rekao, da će se sutra služiti zadušnica u stolnoj crkve za poginule u Brodu, a to bi značilo političku demonstraciju, pa bi ih trebalo zabraniti. Zato da me ministar predsjednik moli, neka bi zabranio to. Odgovorio sam da meni nije o tome ništa poznato, naime nije nikoga bilo kod mene glede te stvari, da bi molio Requiem, ali sam čuo, da su bili kod Knežića kanonika, koji je kustos katedrale, i da im je dozvolio kao što se dozvoljava svima, koji nisu umrli u neprijateljstvu sa Crkvom. Ja ne mogu zabraniti sada jer bi to značilo još više ogorčiti narod.« Stepinac je banu rekao da će se o tome posavjetovati s nadbiskupom Baureom. Ovaj ga je zamolio da mu telefonom javi rezultat svoga razgovora. Stepinac bilježi da je dugo razgovarao sa starim nadbiskupom. Bili su u nedoumici: $\gg$ Ako ne zabranimo ljuto će se srditi Beograd. Ako zabranimo, Hrvati će biti ogorčeni... (nečitko) $\ll^{18}$ Odlučili su ipak dopustiti služenje zadušnica. Stepinac je vidio da je »ogorčenje u masi užasno «. Telefonirao je banu da $\gg$ mi Requiema zabraniti ne možemo jer bi to značilo stvoriti još veći kaos «. Ban ga je upozorio da je biskup Akšamović zabranio služenje zadušnica na području svoje biskupije. »Odgovorio sam - to je njegova stvar, ali ovdje su druge prilike. ${ }^{19}$

Ban Kostrenčić obavijestio je ministra unutarnjih poslova Velju Popovića o susretu sa Stepincem. U ponekim detaljima taj prikaz razlikuje se od onoga što je Stepinac zapisao u Dnevniku. Kostrenčić je svoj razgovor sa Stepincem donio u okviru širega dopisa ministru Popoviću o planiranoj misi zadušnici i akcijama koje je planirao poduzeti s tim u vezi. Izvješće ministru pisao je odmah 22. veljače, kada je izišla po-

\footnotetext{
${ }^{16}$ Letak koji je potpisao Vladko Maček sačuvan je na raznim mjestima i mnogo je puta objavljen u literaturi. Ovdje je korišten prema: HDA, Savska banovina. Odjeljak Upravnog odjeljenja za državnu zaštitu (dalje SBODZ) fond br. 145, k 319,, inv. br. 8656/35, Zadušnice izginulim prilikom nereda u srezu Slav. Brod - održavanje, dopis Bana Kostrenčića 22.2.1935. Ministarstvu unutrašnjih poslova Odelenje za državnu zaštitu na ličnost Gospodina Ministra.

${ }^{17}$ Dnevnik Alojzija Stepinca, I, 120.

${ }^{18}$ Isto.

${ }^{19}$ Isto, 121.
} 
smrtnica dr. Mačeka u kojoj je obavijestio građanstvo Zagreba o pokolju seljaka u Sibinju i na brodskom gradskom groblju i pozvao Zagrepčane da dođu na zadušnicu za seljake $\gg$ koji su u srezu slav. brodskom pali u borbi sa bezobrzirnim režimom $\ll^{20}$. Misa će biti sutradan prijepodne. Posmrtnicu je ban priložio svom dopisu ministru i dodao: »Sličnu posmrtnicu izdali su studenti - separatisti.« Kako se u gradu govorilo $\gg$ da izvesne grupe separatističkih i komunističkih elemenata nameravaju večeras da spreče održavanje raznih zabava i priredaba i prisiljavaju sopstvenike trgovina i drugih javnih lokala da zatvore radnje i da građanstvo ističe crne zastave, to sam u vezi toga naredio upravniku policije strogu pripravnost «. Ban je želio spriječiti svako skupljanje u većim skupinama po ulicama, osigurati zaštitu svih državnih i samoupravnih objekata, i napose spriječiti ometanje priredbi i zabava u raznim lokalima, kao i u »Narodnom Pozorištu «. Odbiti zabave u lokalima i predstave u kazalištu značilo je čistu političku demonstraciju koja je bila kažnjiva. Htio je da Zagreb izgleda kao da se ništa važno nije dogodilo. Naredio je pojačanje straža na gradskim mitnicama »u cilju sprečavanja dolaska seljaka u velikim grupama iz sela u grad, kao i dolazak u većim grupama na zadušnice u Katedralu «. U tom dopisu ban je obavijestio ministra o razgovoru sa Stepincem, kojega je osobno posjetio. »U cilju da se spreči održavanje zadušnica razgovarao sam sa nadbiskupom koadjutorom dr. Stepincem, kome sam izložio da održavanje zadušnica sada nebi bilo nikako podesno jer kako i sam iz osmrtnice može da vidi ovo se čini iz čisto političkih motiva. Dr. Stepinac odgovorio mi je da oni ne mogu zabraniti održanje zadušnica jer se po crkvenim propisima i za razbojnike moraju održavati. Ja sam mu na to napomenuo kako je on (dr. Stepinac) u više mahova predamnom kao i pred ostalim nadležnim faktorima naglasio da će svoje sveštenstvo depolitizovati pa da se nadam da će najmanje dozvoliti da se crkva zloupotrebljava u političke ciljeve, a ovo tim pre što će ovu priliku iskoristiti sutra u crkvi naročito komunistički elementi. Posle ove primedbe zapazio sam da se je trgao i ozbiljno razmišljao šta da učini pa mi je izjavio da će se po tome predmetu posavetovati sa nadbiskupom dr. Bauerom i da će me o rezultatu odmah izvestiti.« Poslije toga ban je telefonski razgovarao s biskupom Akšamovićem koji mu je rekao da on ne će dopustiti zadušnice za pale seljake četrnaest dana, a kasnije samo na zahtjev rodbine poginulih, jer je smatrao da je >održavanje ovih zadušnica sada politička demonstracija što da se ne može i ne sme nikako dozvoliti «. »Oko 21,15 časova saopštio mi je telefonski nadbiskup koadjutor dr. Stepinac da je razgovarao sa g.dr. Bauerom pa da su rešili da se održavanje zadušnica ne može zabraniti jer da bi ovakva zabrana mogla da izazove velike nerede. Kada sam mu napomenuo šta je u tom pogledu raspoložio biskup dr.

${ }^{20}$ HDA, SBODZ, fond br. 145, k 319, inv. br. 8656/35, Zadušnice izginulim prilikom nereda u srezu Slav. Brod - održavanje, dopis Bana Kostrenčića 22.2.1935. Ministarstvu unutrašnjih poslova Odelenje za državnu zaštitu na ličnost Gospodina Ministra Beograd. 
Akšamović, izjavio je da su ovde drukčije prilike... $\ll{ }^{21} \mathrm{U}$ svojem zapisu Stepinac ne spominje komunističku opasnost koju mu je predstavio ban i nad kojom se, prema dopisu bana ministru Popoviću, Stepinac $\gg$ trgao i ozbiljno razmišljao $\ll .{ }^{22}$

Pod nadnevkom 23. veljače Stepinac bilježi: »Danas ujutro došao je k meni dr. Lochert da me pita jesam li ja zbilja zabranio zadušnice, odnosno odbio da ih držim. Rekao sam da kod mene nije bilo nikakvog delegata koji bi me za to zamolio, ali sam čuo od tajnika da je netko bio (dr. Jančikovićc ${ }^{23}$ ). Rekao sam da ja nisam zabranio zadušnica usprkos presije, koju je na mene činila državna vlast. Dr. Lochert se zadovoljio. Tako su se zadušnice zaista održale. Ogromna masa svijeta nagrnula je u katedralu. Policija se sakrila i iz prikrajka motrila. Nakon sv. Mise masa je aklamirala dr. Mačeku a iza toga zaorile su po gradu hrvatske davorije, 'Lijepa naša', 'Još Hrvatska', 'Oj Hrvati' itd... $\ll^{24}$

Misa zadušnica koje se toliko bojao ban Kostrenčić i od koje je strahovao sam premijer Jevtić, kao i ministar unutarnjih poslova Velja Popović, održana je 23. veljače 1935. godine u katedrali u Zagrebu. Upravnik policije u Zagrebu Stanoje Mihaldžić izvijestio je bana da je misu naručio dr. Tomo Jančiković, odvjetnik, »poznati separatista «. U izvješću čitamo: »Kad je isti plaćao pristojbu za te zadušnice u iznosu od 540 dinara, zahtevao je da se potvrda o uplati izda na ime dr. Vladka Mačeka, što je doista i učinjeno.« Prema tomu izvješću misi »za poginule seljake buntovnike u srezu slavonskobrodskom « bilo je nazočno šest do sedam tisuća ljudi, među kojima i istaknuti političari i njihovi suradnici: Vladko Maček, Ante Trumbić, Kerubin Šegvić, ${ }^{25}$ odvjetnik Josip Reberski, odvjetnik Matija

${ }^{21}$ Isto.

${ }^{22}$ Isto.

${ }^{23}$ Tomo Jančiković (1899. - 1951.), političar, odvjetnik i publicist. Nakon atentata u beogradskoj skupštini 1928. godine pristupio je HSS-u i postao jedan od najutjecajnijih njegovih članova. Uhićen je i u veljači 1948. godine osuđen na deset godina robije zbog navodne suradnje s okupatorom. Umro je u Srijemskoj Mitrovici u zatvoru pod nerazjašnjenim okolnostima: Hrvatski biografski leksikon, VI, Zagreb, 2005., 306-308.

${ }^{24}$ Dnevnik Alojzija Stepinca, I, 121.

${ }^{25}$ Kerubin Šegvić (1867. - 1945.), svećenik, hrvatski povjesničar i književnik. Neke je radove potpisivao i pseudonimom Peirre Lucki. Gimnaziju je pohađao u Zadru, a franjevački novicijat u Kopru. Zaređen je 1889. godine, no kasnije je izišao iz franjevačkoga reda, ali je ostao svjetovni svećenik na službi u Kopru, Gorici i Trstu, a zatim je predavao kao profesor na Korčuli, Kopru i Kotoru. Godine 1895. prešao je u Zagreb gdje je studirao slavistiku. Bio je pristalica Stranke prava. Godine 1906. otišao je u Sarajevo gdje je uređivao za Hrvate u Bosni i Hercegovini vrlo važna glasila: Hrvatsku narodnu zajednicu i Napredak. Zbog hrvatskih stavova protjeran je iz Sarajeva, pa se vratio u Zagreb, gdje se uključio u polemiku starih i mladih kao jedan od glavnih teoretičara i ideologa struje starih. Poslije Prvoga svjetskoga rata osnovao je i uređivao važne hrvatske listove: Hrvat, Hrvatski list u Osijeku, Hrvatsku riječ u Splitu, Hrvatsku smotru (1933.). Zbog članka Ustaj bane, Hrvatska te zove, 
Mintas, dr. Ivan Protulipac, ${ }^{26}$ odvjetnik i vođa Križara, Juraj Gašparac, bivši veliki
župan, te sveučilišni profesor Janko Šimrak..$^{27}$ Zadušnicu je služio opat Prvostolno-

izbavi nas iz nevolje ove bio je osuđen na tri mjeseca zatvora. Zastupao je teoriju o gotskom podrijetlu Hrvata na temelju podataka Tome Arhiđakona iz 13. stoljeća. Objavio je studije o Kumičiću, Kvaterniku, Anti Starčeviću, G. Martiću, povijesne romane Lopudska sirotica i Posljednji Kotromanići te niz književnih kritika. Uspješniji je kao pisac za djecu. Poslije Drugoga svjetskoga rata komunisti su ga odmah uhitili i osudili na smrt: Šegvić, Kerubin, u: Hrvatska enciklopedija (mrežno izdanje), S. Ravlić (ur.), http://www.enciklopedija.hr/natuknica.aspx?id=59414 (27.9. 2018.); jedan od glavnih krimena navedenih u optužnici jest da je zastupao teoriju o gotskom podrijetlu Hrvata jer da je time $\gg$ nastojao dati teoretsku i ideološku podlogu i opravdanje cjelokupnom zločinačkom radu zloglasne terorističke organizacije 'ustaša', a sve to u namjeri da izazove bratoubilački rat i da raspiri rasnu mržnju među narodima Jugoslavije « (citirano prema A. BAKOVIĆ, Hrvatski martirologij XX stoljeća, Zagreb, 2007., 615-616.). Prof. Šegvić osuđen je zajedno s patrijarhom Germogenom i zagrebačkim muftijom Ismetom Muftićem te evangeličkim biskupom Filipom Poppom. Vidi: S. KOŽUL, Martirologij Crkve zagrebačke, Zagreb 1998., 120-121.

${ }^{26}$ Dr. Ivan Protulipac (1899. - 1946.), odvjetnik, jedna od najistaknutijih osoba u organiziranju hrvatskoga katoličkoga pokreta između dvaju svjetskih ratova. Gimnaziju je završio u rodnom Karlovcu, a pravo u Zagrebu, gdje je i doktorirao. Od 1923. do 1927. godine bio je odvjetnički pripravnik u Karlovcu, Bjelovaru i Zagrebu, u kojem je otvorio odvjetnički ured i kao odvjetnik radio do 1945. godine. Bio je prvi predsjednik Orlovstva i Križarstva. Godine 1923. izabran je za predsjednika $\mathrm{Hr}$ vatskoga orlovskog saveza nakon što je došlo do ujedinjenja Omladinskog saveza i Orlovskog podsaveza. Zbog svoga djelovanja Protulipac je više puta uhićen. Kad je kralj Aleksandar Karađorđević uveo diktaturu, zabranjen je bio Hrvatski orlovski savez. No početkom 1930. godine u odvjetničkoj pisarnici dr. Protulipca osnovana je organizacija katoličke mladeži Križari, po uzoru na francuski istoimeni pokret kao strogo crkvena organizacija, koja je imala biti dio Apostolata molitve. Na čelu Križara bio je dr. Protulipac, koji je bio predsjednik Velikoga križarskoga bratstva (1931. - 1938.). Pravila je potvrdio nadbiskup Bauer, ali nisu policijske vlasti. Uhićen je nakon što je zaplijenjeno jedno pismo iz kojega su vlasti zaključile da su Križari zapravo obnovljeni Orlovi. Godine 1936. nadbiskup Stepinac postavio ga je za predsjednika Katoličke akcije Zagrebačke nadbiskupije, no ubrzo ga je zamolio da se povuče pa je sam preuzeo njezino vodstvo zbog sukoba raznih frakcija unutar pokreta. Kad je došlo do sukoba unutar KA-a, početkom 1939. godine Protulipac je osnovao društva Mladost i Preporod. Gradski križari, osobito u zagrebačkoj nadbiskupiji, pošli su za njim, što Stepinac nije odobravao. Tijekom Drugoga svjetskoga rata tri je puta uhićen jer se nije slagao s Pavelićevim režimom. U svibnju 1945. godine Ivan Protulipac emigrirao je u Italiju. Njegovo »zauzimanje za progonjene i njegova iznimno velika aktivnost u organiziranju katolika razlogom je zašto ga je tajni agent novouspostavljene jugoslavenske policije ubio u Trstu « 31. siječnja 1946. godine. Njegovo tijelo ekshumirano je 24. lipnja 1993. godine i preneseno je u Zagreb. Položeno je u grobnicu obitelji Merz na mjestu gdje je ležao njegov prijatelj i suborac bl. Ivan Merz, čiji su posmrtni ostatci preneseni u baziliku Srca Isusova. Vidi: J. KRIŠTO, Hrvatski katolički pokret (1903. - 1945.), Zagreb, 2004., passim; L. ZNIDARČIĆ, O stogodišnjici rođenja Ivana Protulipca. Prilog povijesti hrvatskoga katoličkog pokreta, u: Kolo. Časopis Matice hrvatske 2(ljeto 1999.), 493-529. Njegova egzekucija i kasnije blaćenje bili su u službi desetkovanja hrvatske inteligencije i uhodane komunističke prakse nemilosrdnoga obračuna sa svim neistomišljenicima.

${ }^{27}$ Janko Šimrak (1883. - 1946.), hrvatski grkokatolički biskup, sveučilišni profesor. Filozofsko-teološki studij polazio u Zagrebu i Innsbrucku, gdje je i doktorirao 1910. godine. Od 1925. godine redoviti je profesor istočnoga bogoslovlja na Katoličkom bogoslovnom fakultetu u Zagrebu. Bi- 
ga kaptola Stjepan Korenić, ${ }^{28} \gg$ poznati i istaknuti Pribićevićevac «, koji nije držao nikakav govor. Dr. Maček došao je autom i kad je ulazio u katedralu »palo je sa strane sakupljenih nekoliko pojedinačnih poklika: 'Živio dr. Maček vodja hrvatskog naroda' i 'Slava mučenicima'«. Kad je zadušnica završila »zapevala je jedna grupa mladića već pri izlazu 'Lepu našu domovinu', a palo je ponovno nekoliko poklika 'Živio dr. Maček'. Medjutim su prisutni ove pevače i poklike ušutkivali.« Maček nije mogao ući u auto od ljudi koji su ga sa svih strana opkolili i pozdravljali, pa se vratio u crkvu i kroz nadbiskupski dvor izišao na istočni izlaz u Vlašku ulicu. »Za to vreme skupljeni omladinci stalno su aklamirali dr. Mačeka.« Neka skupina mladića pokušala je prosvjedovati, »no brzom intervencijom policiskih organa sprečeni su u svojoj nemeri«. I dalje su padali poklici: »'Živio Maček', 'Slava mučenicima' 'Živila slobodna i samostalna Hrvatska', 'Dolje ubojice.'« Nakon što je ona skupina mladića spriječena u namjeri da prosvjeduje pred katedralom, pokušali su to učiniti na Jelačićevu trgu, u Ilici, Preradovićevoj i Deželićevoj ulici, pred stanom dr. Ma-

skup je Križevačke grkokatoličke eparhije od listopada 1943. godine. Ustaške vlasti su se protivile tom imenovanju. Bio je vrlo aktivan u znanstvenom, medijskom i političkom životu: tajnik $\mathrm{Hr}-$ vatske pučke stranke, poslanik u beogradskoj Narodnoj skupštini (1919. - 1923.), istaknuti član Hrvatskoga katoličkoga pokreta; urednik zagrebačkih Novina i Narodne politike te ravnatelj Hrvatske straže (1923. - 1941.). Glavna su mu djela: Povijest Marčansko-svidničke eparhije i crkvene unije u jugoslavenskim zemljama (1924.), Grkokatolička crkva u Jugoslaviji. Nakon stvaranja Nezavisne Države Hrvatske protivio se donošenju rasnih zakona, a kasnije je pomagao antifašistički pokret. Odmah po završetku rata uhićen je, ali nije bilo nikakvih dokaza protiv njega, pa je pušten, no ubrzo je završio u bolnici i umro: Hrvatska enciklopedija, X, Zagreb, 2008., 469.

${ }^{28}$ Stjepan Korenić (1856. - 1940.), svećenik, profesor, novinar, urednik. Diplomirao je na Bogoslovnom fakultetu i zaređen je za svećenika 1881 . godine. Bio je kateheta u Višoj djevojačkoj školi i Ženskoj učiteljskoj vježbaoni te nastavnik u Ženskoj učiteljskoj školi sestara milosrdnica od 1881. do 1886., nastavnik u riječkoj gimnaziji od 1886. do 1887., zatim u Zagrebu predstojnik nauka u Plemićkom konviktu od 1887., kateheta u Ženskom liceju od 1892. do 1896., kanonik Zagrebačkoga kaptola, obnašao je više crkvenih dužnosti. Bio je odgovorni urednik Katoličkoga lista od1896. do 1904., urednik i suradnik Prijatelja naroda od 1904. do 1906. Bio je gradski zastupnik zagrebačkoga Gradskoga vijeća od 1910. do 1919. Jedan je od važnih poticatelja organiziranja Prvoga hrvatskoga katoličkoga kongresa, čiji je tajnik Središnjega odbora. Protivnik je Čiste stranke prava, koja mu je zamjerala jugoslavenstvo. Nakon Prvoga svjetskoga rata pristajao je uz Pribićevićevu unitarističku Demokratsku stranku. U vrijeme diktature bio je veza Mačeka i Vildera s Pribićevićem, koji je bio u izbjeglištvu. Kao urednik KL-a pisao je o aktualnim crkvenim i društvenim problemima. Polemizirao je sa srpskim listovima (Srbobran, Srpski Sion, Branik) braneći rad nadbiskupa Stadlera i stajališta Katoličke Crkve. Bio je protiv suvremenih smjerova u književnosti i likovnoj umjetnosti pa je kritizirao verizam i modernu. Polemizirao je s Franom Folnegovićem i Š. Brusinom o liberalnim idejama i masonstvu. Vodio je polemike i o vjeronaučnim udžbenicima. Surađivao je u mnogim onodobnim listovima: Katolički list, Obzor, Narodna obrana, Novom listu, Hrvat (1928.), Novo doba (1928.), Novosti (1928., 1933., 1935. - 1936.), Jutarnji list (1929., 1934. - 1935., 1938. - 1940.), Spomenici vrhbosanskoj 1882. - 1932. (Sarajevo 1932.).Vidi: Hrvatski biografski leksikon, VII, Zagreb, 2009., 619-620. 
čeka, »no na svim tim mestima su brzom intervencijom smesta rastureni $\ll$, piše zapovjednik policije. Na pojedinim mjestima čuli su se pojedinačni poklici: »'Živila samostalna Hrvatska,' 'Dole Beograd', 'Dole Srbija,' 'Dole krvavi režim.'« Masovnoga odziva na te poklike nije bilo. Uhićeno je 15 osoba za koje je utvrđeno da su ih izvikivali. Uhićenici su uglavnom radnici i studenti. U svom izvješću upravitelj policije posebno oštro kritizira nadbiskupa Stepinca, ističući to kao temeljni stav $\gg$ građanstva «. »U redovima gradjanstva naročito se kritikuje držanje nadbiskupa koji ne samo da je dozvolio održavanje zadušnica u katedrali velikom pompom za ubijene buntovnike, nego je naredio, da 1 sat prije početka zadušnica zvoni veliko zvono, koje inače zvoni samo u najsvečanijim zgodama i za slučaj velikih opasnosti. Ovom zvonjavom uzbunio je ceo grad i gradjanstvo tako da su mnogi iz puke znatiželje pošli ka crkvi, kuda inače ne bi ni došli, pa je usled toga i broj prisutnih u crkvi znatno porasao.« U dopisu se ističe kako su mnogi nepoznati ljudi telefonski ili osobno tražili od trgovaca da zatvore svoje radnje za vrijeme zadušnice. Svi trgovci u Ilici, na Jelačićevu trgu i u Jurišićevoj ulici zatvorili su svoje trgovine, dok je $\gg$ u drugim delovima grada vladao posvema normalan život $\ll{ }^{29}$ Upravnik policije u Zagrebu Stanoje Mihaldžić nije bio daleko od istine, iako su njegovi zaključci o krivnji nadbiskupa Stepinca krajnje površno određeni ponajprije činjenicom njegova visokoga činovničkoga mjesta u policiji, a očito i njegovom nacionalnom pripadnošću. Iako sam nije poticao održavanje misa zadušnica za sibinjske žrtve, nadbiskup Stepinac odobrio ih je, što je tada bila izuzetno hrabra odluka, koja mu je priskrbila teške osude nositelja vlasti. To je samo jedan od primjera, ali vrlo važnih primjera, kojim je mladi nadbiskup pokazao da je on osobno, a preko njega i Katolička Crkva, u obrani hrvatske nacionalne svijesti vrlo važan stup hrvatskoga naroda, njegova nacionalnoga i vjerskoga identiteta naspram velikosrpskih presizanja, koje je režim provodio pod krinkom jugoslavenskoga unitarizma.

U vezi s tim događajima Stepinac je primio anonimno pismo, pisano 20. veljače, $u$ kojem ga nepoznati pošiljatelj poziva da odlučnije prepozna svoju ulogu u narodu. Pismo je nalijepljeno u Dnevniku. Anonimni autor pisma ističe:

\section{$\gg$ Preuzvišeni Nadpastire!}

Znademo, da je i Vama stigla vijest o groznom pokolju hrvatskih seljaka u Sibinju kod Broda, kroz krvoloke, srpske žandare, jer Srbi znadu biti junaci samo onda, kada se do zubiju naoružaju protiv golorukih protivnika. Svako pravo hrvatsko oko danas je puno suza i zgraža se nad ovakovim barbarlukom, koje se dnevno vrše na jadnom, nenaoružanom hrvatskom narodu u svim krajevima naše izmučene majke domovine Hrvatske!

${ }^{29}$ SBODZ, fond br. 145, k. 319, inv. br. 8656/35, Uprava policije u Zagrebu, 23. februara Pov.-Broj 5124/1935. Predmet: Zadušnice za poginule seljake u Brodskom srezu - izveštaj. 
U Vašoj ruci Preuzvišeni leži moć, da se stane na put ovoj Golgoti hrvatskoga naroda. Vas hrvatski katolički kler štuje nadnaravno, jer Vas smatra i vidi u Vama svoga duševnoga vodju, kakovoga još nikada nije imao, a sluša Vas, kao što su apoštoli slušali našega Isusa Krista. Dajte im nalog, ili bar mig, da oni, kao vlaški i srpski popovi, sa propovedaonice opišu svome puku ovaj grozni pokolj, da pozovu hrvatski narod na skup u ovim teškim vremenima kada smo u gorem igu, nego što je bila turska raja, da se slože i unisono uskrate svaku pomoć svojim krvolocima... Neće i ne mogu oni zatvoriti sve katoličke svećenike, ako ovi budu solidarni samo naše svećenstvo i naša katolička vjera nas mogu izbaviti iz ovoga ropstva...

Gospoda Generali srpski spremaju se, ako bi danas sutra morali napustiti naše krajeve, da naš mili Zagreb pretvore u prah i pepeo, a to im je i slično, jer su tako navikli suprot golorukoga neprijatelja ratovati...

Pomozite Preuzvišeni, spasite nas iz ovoga ropstva i nedajte da propadamo. Vaš moćni zagovor kod svetoga OCA PAPE može nas spasiti.

Zato Vas mole svi katolici Hrvati iz Zagreba, kojih nas imade dosta hiljada i koji smo spremni, ženjske i muški latiti se kolca i motike da se odupremo nametnutom nam neprijatelju srpsko-vlaškom. 20./II.1935.« ${ }^{30}$

Pod nadnevkom 25. veljače Stepinac piše: $\gg$ Danas sam bio kod bana dr. Kostrenčića da interveniram zbog nekih novih nasilja što su ih počinili pojedini sreski poglavari. G. ban gorko mi se tužio što sam dozvolio zadušnicu za poginule u Brodu i okomio se na svećenika Praskića. Rekao sam da ja Praskića ni najmanje ne branim, ali to nije uzrok nemirima u Sibinju i Brodu. Uzroci su rekoh mnogo dublji, a to su što nema ravnopravnosti u ovoj državi i što nema u njoj pravde već žandari rade što ih volja. G. ban kušao je naravski da brani stranu vlade, ali sam mu bjelodano dokazao da je uzalud govoriti o ravnopravnosti kad je u praksi nema a puna su je usta. $\ll^{31}$ $\gg$ Kako se vidi 'Novostima' odnosno vladi izvrsno je došao ovaj Praskić kao naručen. Mi ga ni najmanje ne branimo ako je kriv, ali tvrdimo da on nije uzrok (ist. u originalu) nemirima koji su se desili nego oni leže mnogo dublje. Međutim vlada neće o tome čuti. $\ll^{32}$

\footnotetext{
${ }^{30}$ Dnevnik Alojzija Stepinca, I, 120a.

${ }^{31}$ Isto, 124.

${ }^{32}$ Isto, 126.
} 


\section{Mise zadušnice u Zagrebačkoj nadbiskupiji za ubijene sibinjske žrtve}

\subsection{ZaDUŠNICA U KaRLOVCU}

I u mnogim župama Zagrebačke nadbiskupije služene su mise zadušnice za ubijene u okolici Broda. Vlasti su to najprije pokušale spriječiti, ali je odziv vjernika bio tako velik da se vidjelo da je najmudrije dopustiti odavanje pijeteta žrtvama. Zadušnice su, prema sačuvanim dokumentima, održane u četrdeset dvije župe. $\mathrm{Na}$ njima je bilo nazočno preko dvadeset tisuća vjernika. Samo na zadušnici u katedrali u Zagrebu bilo je, kako je već rečeno, prema procjeni samih državnih vlasti, šest do sedam tisuća vjernika.

Zanimljiv je primjer održavanje mise zadušnice u Karlovcu u Župi Svetoga Trojstva koju su vodili franjevci. Župnik i gvardijan Gjuro Bencetić obavijestio je pismom nadbiskupa Stepinca da su ga zamolili 23. veljače da se služi misa zadušnica za pale seljake u Sibinju i Brodu. Kako je čuo da je služena misa zadušnica u Zagrebu u katedrali, i on je prihvatio da se u župi služi misa za poginule 26. veljače. Znajući da će policija biti nezadovoljna time, on je na nedjeljnoj misi oglasio održavanje zadušnice u Župi Svetoga Trojstva ovako: »Kad se već sa službene strane javlja i novine o tom pišu, onda se može o tom i u crkvi govoriti. Braćo i sestre! Zamoljeni smo, da odslužimo svečane zadušnice za pale seljake 19.II u Sibinju i 20.II u Sl. Brodu. Ove će se zadušnice služiti 26.II u utorak u 9 sati u ovoj crkvi. Pozivam Vas, da ovim zadušnicama prisustvujete. Svrha je zadušnicama pomoliti se za preminule, a nipošto, da se revolucioniraju duše Vaše. Ja Vas dapače molim da se vladate mirno i ne dadete nikomu povoda, da se Vašem vladanju što zamjeri. Molim Vas i to, pokoravajte se zakonu! Čuvajte se izazivača! Poštujte zakon! Tako nas uči naša sv. vjera. Sv. Apostol lijepo kaže: 'Svaka vlast [je] od Boga!' niko nam pako neće zamjeriti, što molimo za pale. To je naša dužnost.« Nakon toga su župnika posjetila tri detektiva i tražila da se javi u policiju, kamo ga je zvao predstojnik Grgurić. Župnik je odbio primiti pozivnicu i otići u policiju »radi te stvari (zadušnice) « ističući da će se $\gg$ samo sili pokoriti «. »Nisam si svjestan nikakove krivnje, pa ne znam zašto bi tamo išao. Ako mene g. Dr. Grgurić treba, neka dodje k meni. I opet sam rekao da se samo sili pokoravam. « Župnik u pismu ističe da je htio samo upozoriti nadbiskupa Stepinca da zna o čemu je riječ. Očekivao je naime da će ga policija tužiti banskoj upravi, a ona tražiti posredovanje kod Nadbiskupa, pa ga želi upoznati s pravim stanjem. Na poleđini pisma Stepinac je svojom rukom napisao: »Odgovorio sam mu privatno. Stepinac $\ll^{33}$

Što je odgovorio nadbiskup Stepinac Bencetiću, autoru ovih redaka nije poznato. Njegovo pismo, nažalost, nije sačuvano. Izvješća Predstojništva gradske policije iz

\footnotetext{
${ }^{33}$ Nadbiskupijski arhiv Zagreb, Nadbiskupski duhovni stol, br. 1869/1935.
} 
Karlovca Banskoj upravi nude zanimljive mogućnosti kao odgovor. Glavni gradski policajac dr. Grgurić u izvješću Banskoj upravi Odsjeku za državnu zaštitu ističe da je pozvao Bencetića na razgovor, da je ovaj to odbio, a da mu je on na to poručio da će biti osobno odgovoran za nerede. U izvješću predstojnik policije obavještava da je misa zadušnica održana, da ju je služio gvardijan Gjuro Bencetić, da je bilo oko 300 ljudi na misi. Na završetku zadušnice Bencetić je, prema izvješću predstojnika policije, rekao sljedeće: $\gg$ Mi smo se sastali da odamo poštu poginulima u Sibinju, za koje neznamo da li su poginuli nevini, ali kako smo čitali, izgleda, da su se sukobili sa zakonom. Gledajte da izbjegavate kod ovih izbora sukobe sa vlastima, jer se vlastima treba pokoriti, a sada gledajte da se mirno raziđete svojim kućama.« »Nakon dovršenih zadušnica prisutni su se mirno razišli i nije došlo ni do najmanjeg incidenta. Za vrijeme zadušnice bilo je zatvoreno par dućana. ${ }^{34}$ Još se jednom na zadušnicu u Karlovcu osvrnuo predstojnik gradske policije. Podsjetio je da je zadušnica prošla u miru, a »Bencetić je poslije zadušnica održao govor, kojim separatiste nisu bile zadovoljne i predbacivale $\mathrm{mu}$, da je govorio kao da je od policije inspiriran«. Uzimajući to u obzir, predstojnik policije ističe: »...u interesu stišavanja strasti i davanja zaboravi medju gradjanstvom Sibinjskog dogadjaja, nisam našao za potrebno da Bencetića uopšte pozivam na odgovornost. $\ll^{35}$

O tom slučaju ban je izvijestio ministra unutarnjih poslova Velju Popovića. Upoznao ga je s razvojem događaja: predstojnik gradske policije »poverljivim putem « doznao je da će gvardijan Gjuro Bencetić služiti misu zadušnicu za seljake poginule u Slavonskom Brodu. On ga je pozvao na razgovor s namjerom da ga privoli da od toga odustane. No župnik Bencetić nije se odazvao, na što je Banska uprava naložila da se protiv Bencetića poduzmu stroge mjere. Bencetić je poručio da će on misu služiti $\gg i$ da red i mir neće biti narušeni «. Misa zadušnica služena je 26 . veljače $u$ nazočnosti 300 osoba. Ban je doslovno ponovio govor župnika Bencetića na kraju zadušnice iz izvješća koje mu je podnio predstojnik policije. Uočeni su neki državni službenici sa željeznice na zadušnici. Nakon završene mise zadušnice svi su se mirno razišli $\gg$ i nije došlo ni do najmanjeg incidenta $\ll .{ }^{36}$

Taj smo slučaj malo opširnije opisali jer je izravno vezan za nadbiskupa Stepinca. Ne znamo je li Stepinac savjetovao župniku i gvardijanu da tako nastupi i kaže, kako je to opisano u izvješćima predstojnika policije i bana Kostrenčića. Možda je razbo-

\footnotetext{
${ }^{34}$ SBODZ, fond br. 145, k 319, inv. br. 8656/35., Predstojništvo gradske policije Pov. broj 315/1935. Zadušnice za seljake poginule u Slavonskom Brodu.

${ }^{35}$ SBODZ, fond br. 145, k 319, inv. br. 8656/35., Primljeno 12./III. 1935.

${ }^{36}$ SBODZ, fond br. 145, k 319, inv. br. 8656/35., Kraljevska banska uprava Otsek za državnu zaštitu Ministarstvu unutrašnjih poslova u Beogradu 27. 2. 1935.: Zadušnice za seljake poginule u Slavonskom Brodu.
} 
riti župnik i gvardijan sam procijenio kako se treba ponašati i što savjetovati vjernicima jer je vidio da se predstavnici vlasti ne libe upotrijebiti oružje i ubiti. Upravo je brodski primjer to najbolje pokazivao.

\subsection{PJESME I POKLICI NA ZADUŠNICAMA}

Rečeno je da je misa zadušnica služena u 42 župe Zagrebačke nadbiskupije. Gotovo nigdje nije bilo manje od sto ljudi. Najviše je bilo u Zagrebu (6000 - 7000 ljudi), u Kravarskom 1200 ljudi, Mariji Gorici 800, Staro Čiče 800, Vukovini 800, Stenjevcu 700, Vrapču 500, Samoboru 600, Svetoj Nedelji 500, Križu 500, Velikoj Gorici 500, Pešćenici 400, Brdovcu 400, Bjelovaru 400, Karlovcu 300, Brinju 315 ljudi itd. ${ }^{37}$

Izvješća o ponašanju naroda na misama zadušnicama podnosili su kotarski načelnici i predstojnici policije te komandiri žandarmerije. Zanimljivo je primijetiti da su izvješća komandira policije i žandarmerije redovito pisana ćirilicom, a mise zadušnice označavaju kao »zadušnice za seljake-buntovnike kod Slavonskog Broda «. Samo poneki kotarski načelnici svoje dopise pišu na isti način. Kotarski načelnici, koji sebe uvijek zovu »sreski načelnici«, bili su dužni podnositi izvješća što su poduzimali kao sigurnosne mjere za održavanje zadušnica. Pojačavale su se žandarske jedinice, slali doušnici u crkve, prisluškivali telefoni, otvarala pisma. Posebno je praćen telefon i pošta dr. Mačeka. Predstojnik gradske policije u Brodu izvijestio je 22. veljače Kr. bansku upravu da je Maček poslao brzojav 21. veljače brodskom odvjetniku Filipu Markotiću »sledeće sadržine «: »Javi odmah telefonski ili telegrafski tačna imena svih žrtava - Vlatko.« Zatim nastavlja u izvješću da je 22. veljače u 11 sati prijepodne dr. Markotić nazvao stan dr. Mačeka »i njemu lično na telefonu citirao imena svih, koji su prilikom sukoba sa žandarmerijom nastradali«. Markotić je rekao dalje da je »svuda u srezu potpuni mir, samo da ima 'more uhapšenih'«. Dr. Maček priopćio je sugovorniku da će se $\gg$ u Zagrebu za poginule držati zadušnice, našto mu je Dr. Markotić odgovorio da bi i on to u Slav. Brodu učinio, ali da zna unapred da to Pretstojništvo gradske policije u Slav. Brodu neće dozvoliti. S tim se je njihov razgovor završio uz dodatak sa strane Dra Markotića da bi i on imao još mnogo toga reći, ali da je to telefonom vrlo nezgodno $\ll^{38}$. Je li predstojnik policije htio samo istaknuti svoju revnost u službi ili je točno prenio Markotićev telefonski razgovor s Mačekom, ne predstavlja, zapravo, nikakvu dvojbu. Nositelji represivno-

\footnotetext{
${ }^{37}$ Ti podatci navedeni su prema informacijama koje se mogu naći za pojedina mjesta u: SBODZ, fond br. 145, k 319,inv. br. 8656/35, Zadušnice izginulim prilikom nereda u srezu Slav. Brod - održavanje.

${ }^{38}$ SBODZ, fond 145, k 139, inv. br. 8656/35., Pretstojništvo gradske policije za grad Slav. Brod, 22. februara 1935., Predmet: Markotić dr. Filip advokat u Slavonskom brodu telefonski razgovor sa Drom Vlatkom Mačekom.
} 
ga režima na brodskom području svoju ulogu u služenju tomu režimu najbolje su pokazali nekoliko dana ranije kad su ubili seljake u Sibinju i na brodskom groblju.

U jednom dopisu zamjenik bana dr. Stevan Hadži upozorio je kotarske načelnike: $\gg$ Po instrukcijama iz Zagreba počele su da se po pojedinim mestima priređuju zadušnice za seljake, koji su poginuli prilikom poslednjih incidenata u Slavonskom Brodu. $\ll$ No jedva da se ta inicijativa može pripisati »instrukcijama iz Zagreba «. Izvori jasno govore da su se seljaci sami osjetili ponukani izraziti poštovanje poginulim seljacima u brodskim selima i da im za to nije trebao politički mentor. Svakako da je prva zadušnica, služena u Zagrebu u katedrali, bila važna da se pijetet oda i po provincijalnim mjestima. Letak dr. Mačeka potajno se nosio danju i noću po selima i gradovima i na razne načine širio. Najčešće je čavlićem pribijen na drvo ili je potajno noću stavljan ispod vrata, npr. u Kostajnici. Tu je napravljen novi letak Hrvatskom narodu Kostajnice i hrvatskih sela u kojem su navedena sva imena ubijenih u okolici Slavonskoga Broda i pozvani su ljudi na zadušnicu u Kostajnici. »Primjer glavnoga grada Zagreba koji im je 23. ovog mjeseca dao dostojnu i bratsku poštu treba da slijedi i Kostajnica zajedno sa svim selima, zajedno sa svim poštenim ljudima bez razlike na narodnost a koji stoje na fronti pravde. « Letak završava riječima: »Slava hrvatskim seljačkim velikanima! ${ }^{39}$ Mačekov letak nađen je u Senju, ali je brzom intervencijom gradske policije zaplijenjen, pa je spriječeno njegovo raspačavanje. Istu je sudbinu doživio letak u bjelovarskom području. Zadušnica je bila zakazana za 28. veljače 1935. godine. Odbor za organizaciju zadušnice pisao je: »Dužnost je da se ovoj velikoj i teškoj narodnoj boli i tuzi cijelog hrvatskoga naroda pridružimo i mi gradjani, radnici i seljaci grada i kotara bjelovarskoga, pa zato pozivamo i molimo svekoliko pošteno i svijesno narodno gradjanstvo, seljačtvo i radničtvo, da budemo sudionici i manifestiramo našu veliku žalost nad ovim strahovitim gubitkom života hrvatskih seljaka.« Predstojnik gradske policije u Bjelovaru izvješćuje da je za zadušnicu dao prilog dr. Ivan Lebović, koji je u svojoj odvjetničkoj kancelariji dao napraviti letke, kojima se poziva ljude svih slojeva na misu. Dan prije, piše glavni gradski policajac, skupio je Lebović navečer $30 \gg$ separatističkih i komunističkih omladinaca iz Bjelovara u nakani da ih uputi da nakon zadušnice demonstriraju pred crkvom «. Upozoreni da policija dolazi, mladići su se razbježali, ali predstojnik policije obećava da »protivu dr. Lebovića i saučesnika na sastanku provesti će se propisan policijski postupaka, te o rezultatu izvjestiti $\ll_{.}^{40}$

Komandir zagrebačke žandarmerijske čete obavijestio je Kraljevsku bansku upravu da je raspačano 10 letaka pisanih pisaćim strojem pod naslovom $\gg$ Hrvatima iz sviju sela opštine Vrapče! U borbi sa bezobzirnim režimom poginuli su dana 18. i 19.

\footnotetext{
${ }^{39}$ SBODZ, fond br. 145, k 139, inv. br. 8656/35., Kostajnica 27. II. 1935.

${ }^{40}$ SBODZ, fond br. 145, k 139, inv.br. 8656/35., Bjelovar 27. februara 1935., Pov. Broj: 287-1935.
} 
veljače u selu Sibinju te kod Slavonskog Broda naša braća Hrvatski seljaci i to njih 14 junaka. Ove žrtve zavile su cijeli hrvatski narod u tugu. Po cijeloj našoj domovini održavaju se zadušnice za pale junake. U župnoj crkvi Sv. Barbare u Vrapču jesu zadušnice dne 1. ožujka 1935. (petak) u 10 sati u jutro. Pozivaju se svi zadušnicama da prisustvuju, da pokažu svoje poštovanje mrtvima i svoju narodnu svijest. Prema izvješću komandanta zagrebačke žandarmerije bilo je na zadušnici 500 ljudi. »Posle završenih zadušnica poznati separatista Semen Josip pred crkvom klicao je 'Slava hrvatskim mučenicima', 'Živio dr. Maček', koji poklik je prisutna masa prihvatila. Semen je zatim prisutne opomenuo i pozvao, da se mirno raziđu, što su oni i poslušali.«Žandarmerija »nije imala povoda da interveniše $\ll .{ }^{41}$ I letak u Klanjcu je zaplijenjen. »Sreski načelnik « Klanjca kaže da je otkrio da vlasnik papirnice u Zagrebu Bogumil Šoban posjeduje veliku količinu letaka, pa ga označava kao inicijatora raspačavanja ${ }^{42} \mathrm{Na}$ brodskom području, gdje je zločin počinjen, pronađen je, prema izvješću predstojnika gradske policije, samo jedan letak. ${ }^{43}$

Prema instrukcijama iz Zagreba, kad se vidjelo da se zadušnice ne mogu spriječiti, načelnici i predstojnici policije upućeni su da se treba ponajprije provesti akcija da se one ne održe. Ako se održe, da se spriječi svaki govor, manifestacija ili demonstracija i u crkvi i izvan crkve. U protivnom treba postupiti najstrože po zakonu. Još 23. veljače ban je dobio zanimljiv prijedlog kotarskoga načelnika iz Velike Gorice, gdje se zadušnica trebala održati 25 . veljače. On je predlagao banu da ne treba braniti zadušnice jer ih se ne može spriječiti i da bi bilo bolje da se one održe što prije, svakako prije nego izborna agitacija dođe u odlučniju fazu. S obzirom na iskustvo održavanja zadušnice u Zagrebu, iskustvo iz Velike Gorice, »s obzirom na verovatnosti i daljeg priređivanja ovakvih zadušnica « ban je izrazio mišljenje ministru Popoviću da bi trebalo izdati jedno načelno naređenje, u tom smislu da se $\gg$ održavanje ovih zadušnica ne može sprečavati $\ll$, da vlasti $\gg$ blagovremeno saznaju za priređivanje ovih zadušnica i da svugde gde se ove zadušnice priredjuju, preduzmu sve potrebne mere za održanje reda i mira, da imaju u vidu da održavanje ovih zadušnica može imati samo čisto karakter crkvenog obreda bez ikakovih govora i nedozvoljenih manifestacija ni demonstracija ni u crkvi ni van crkve, te da vlasti imaju protiv krivaca za govore i izgrede $u$ crkvi strogo i hitno postupiti, a same pokušaje i izgrede van crkve sprečavati i protiv krivaca odmah i taktično prema situaciji momenta postupiti i strogo ih kažnjavati $\ll$. Ban je molio ministra da izda

${ }^{41}$ SBODZ, fond br. 145, k 139, inv.br. 8656/35., Savski žandarmeriski puk Pov. Br. 619., 4. marta 1935.

${ }^{42}$ SBODZ, fond br. 145, k 139, inv. br. 8656/35., Klanjec, dne 25. februara 1935., Predmet: Letak dr. Mačka - zapljena.

${ }^{43}$ SBODZ, fond br. 145, k 139, inv. br. 8656/35., Predmet: Letak 'Hrvatskom narodu grada Zagreba' - nalaz u Slav. Brodu, Slavonski Brod dne 26. februara 1935. 
jedan naputak po kojem bi se mogao orijentirati i izdati podčinjenima naredbu za orijentaciju u ponašanju. ${ }^{44}$ Među sačuvanim dokumentima nismo našli jedan takav naputak ministra Popovića. U svim mjestima gdje su održavane zadušnice pojačane su žandarske snage i povećan je broj špijuna.

Služenje misa zadušnica bilo je vrlo riskantno. U narodu je još živo sjećanje na nevjerojatno ubojstvo hrvatskih zastupnika u Narodnoj skupštini, žrtva toga atentata bio je i predsjednik HSS-a Stjepan Radić. Svakodnevna su zatvaranja i ubojstva seljaka i režimu nepoćudnih osoba. No za vrijeme služenja misa zadušnica za ubijene seljake iz okolice Broda nigdje nije bilo sukoba s policijom, nigdje demonstracija. To se sigurno mora upisati u zaslugu i krajnjim naporima župnika da smire atmosferu. Župnici su redovito molili vjernike da u miru budu nazočni na misi i da se nakon nje u miru raziđu. Vlasti su pokušavale doći do informacija tko je uplatio prilog za služenje zadušnica, no župnici su to odbijali, upućujući policiju ili kotarsku vlast na svoje pretpostavljene u Zagrebu. Mise su bile kratke, ponegdje samo 15 minuta (npr. u Jakuševcu). Na kraju je župnik sve molio da se u miru ljudi raziđu. Samo se župnik u Glini odupirao služiti zadušnicu, ali je na kraju i on odslužio misu na kojoj je bilo 170 ljudi. Župnik u Bistri tražio je od uplatitelja zadušnice Franje Rožmana da pismeno jamči da ne će biti nereda. Na misi je bilo oko 250 ljudi, što je bio ozbiljan rizik za uplatitelja. Svugdje su bili nazočni policijski agenti, pazili su na ponašanje vjernika i izvješćivali o svakom pokliku ili pjesmi koja se pjevala. Župnici nisu dopuštali pjevanje pjesama u crkvi, napose ne bilo kakve poklike. »Sreski načelnik « iz Samobora izvijestio je da je župnik u Sv. Nedelji upozorio ljude da budu mirni i da se poslije mise mirno raziđu, »što prisutni nisu u cijelosti poslušali $\ll$. $U$ crkvi je na kraju netko počeo pjevati »Lepu našu «, a na izlazu je drugi viknuo »dolje izdajice «. Sudeći prema dopisu komandira petrinjske žandarmerijske čete Kraljevskoj banskoj upravi o zadušnici u Pešćenici »opština Lekenik, sreza Sisačkog «, kažnjavani su svi oni koji su pjevali određene pjesme ili klicali razne poklike. On kaže da manifestacija poslije zadušnice nije bilo, »sem što su nekoje ženskinje iz Lekenika, nakon dovršene mise cestom pevale plemenske pesme: 'Još Hrvatska nij propala', 'Oj ti vilo, vilo Velebita' i druge razne pesme, radi čega su iste nadležnom sreskom načelstvu prijavljene «. O tome je komandir petrinjske žandarmerije obavijestio i Ministarstvo unutarnjih poslova. Isti događaj opisao je $\mathrm{i} \gg$ sreski načelnik « iz Siska. Osam žena i djevojaka zapjevale su u crkvi $\gg$ Lepa naša $\ll \mathrm{i} \gg \mathrm{Oj}$ Hrvati $\ll \mathrm{i}$ onda se mirno razišle. Seljaci iz Lekenika, vraćajući se kući, pjevali su cestom $\gg \mathrm{Oj}$ Hrvati $\ll, ~ \gg \mathrm{Oj}$ ti vilo, vilo Velebita $\ll$ i $\gg$ Srem, Banat i Bačka mi smo svi za Mačka «. Za te pjesme vjerni činovnik optužuje žene iz Buševca »jer bi inače zadušnice bez tih pjesama prošle «. Da ne bi izazvao veći incident, »sreski načelnik « ograničio se

${ }^{44}$ SBODZ, fond br. 145, k 139, inv. br. 8656/35., Pov - II - DZ 8824/35. 
na kaznenu prijavu $\gg$ radi separatističkih manifestacija $\ll{ }^{45} \mathrm{U}$ Svetoj Nedelji pjevala se $\gg$ Lepa naša «, a na crkvenom dvorištu pali su poklici »dolje izdajice «, na trgu »živila slobodna Hrvatska «. »Sreski načelnik « dr. Mihalić ističe da je otkrio tko je to uzviknuo pa otkriva i njihova imena (Fabijan Lenard iz Rakitja, a drugi povik Julijus Keleković Župan iz Rakitja) i jamči da će obojica biti pozvani na odgovornost $\mathrm{i} \gg$ osjetljivo kažnjeni «. U Vukovini, selu s jakom tradicijom Hrvatske seljačke stranke, gdje je bilo, po iskazu vlasti, 800 ljudi na zadušnici, sve je prošlo »u redu... sem što je na svršetku otpevana Hrvatska himna 'Lijepa naša domovina' «. Pred crkvom su $\gg$ pali poklici «: $\gg$ Slava sibinjskim žrtvama «, »Slava hrvatskim borcima i mučenicima $\ll, ~ \gg$ Slava Stjepanu Radiću «, $\gg$ Živio dr. Maček «, $\gg$ Živila Hrvatska «, »Živio hrvatski narod «. Kod dolaska u crkvu nosila je djevojka Marica Zubek vijenac s natpisom »Slava hrvatskim mučenicima palim u Sibinju «, a djevojka Ljuba Bedek imala je na grudima hrvatsku trobojnicu, »pa je po usmenom naredjenju sreskog pristava Cvetković Branka, koji je bio na licu mesta sa žandarima, dostavljena krivična prijava sreskom načelniku preko Bedek Ljube i ostalih devojaka koje su nosile vence $\ll{ }^{46} \mathrm{Na}$ osnovi prijave žandarske postaje u Velikoj Gorici od 9. ožujka 1935. godine poveden je postupak protiv Ljube Bedek i još šest djevojaka zbog toga što su u crkvu u Vukovini donijele » venac sa dugačkim plemenskim trobojnicama, noseći istovremeno preko grudi plemensku trobojnicu «. Osim toga postupak je pokrenut i protiv Marice Zubek iz Buševca, »koja je donela venac sa crnom trakom na kojoj je zlatnim slovima ispisano 'Slava hrvatskim seljacima u Sibinju' «. »Plemenske trobojnice « nosile su djevojčice ispod četrnaest godina, koje nisu mogle odgovarati pred sudom. No zato su na sud pozvani njihovi roditelji, koji su se branili da nisu znali da će njihove kćeri nositi hrvatske trobojnice. Ipak su kažnjeni s 300 din globe, a u slučaju nemogućnosti plaćanja morali su ići šest dana u zatvor. Mara Zubek, Sara Črnko i Mara Robić kažnjene su »za izazivanje plemenske netrpeljivosti « istom kaznom. One koji su izradili vijence $s$ »plemenskim trobojnicama « kotarsko načelstvo kaznilo je s 500 din globe ili deset dana zatvora u slučaju nemogućnosti plaćanja kazne. Selo Buševec također je bilo važno uporište raspuštene Hrvatske seljače stranke, koja se ipak nije ugasila. ${ }^{47}$

O zadušnici u Vukovini izvijestio je i »sreski načelnik« Velike Gorice najprije telefonom, a onda i pismeno. Misa je bila održana 8. ožujka. »Seljaci iz Vukovine doneli su veliki venac okićen širokom i dugačkom hrvatskom trobojnicom. Taj venac nosilo je osam devojčica i devojaka koje su preko grudi imale široke hrvatske tro-

\footnotetext{
${ }^{45}$ SBODZ, fond br. 145, k 139, inv. br. 8656/35., Sreski načelnik u Sisku, br. 369/35. Sisak 30.marta 1935., Predmet: Zadušnice za mrtve u Sibinju.

${ }^{46}$ Isto, 12. 3. 1935.

${ }^{47}$ SBODZ, fond br. 145, k 139, inv. br. 8656/35., Pov. Br. 450/1935., u Velikoj Gorici dne 18. marta 1935.: Predmet: Zadušnica za pale u Sibinju održane u Vukovini.
} 
bojke. Venac je pleten i priređen kod Đure Vugrića iz Vukovinek.br. 63.« $\gg$ Seljaci iz Buševca doneli su sa sobom veliki venac sa crnim trakama na kojima je zlatnim slovima ispisano: 'Slava palim hrvatskim seljacima u Sibinju'. Protiv lica koja su nosila istaknute plemenske trobojke povest će se policijsko-kazneni postupak.« Ljudi su

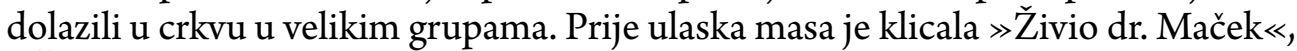
$\gg$ Živila Hrvatska «, »Slava Radiću «, »Slava palim žrtvama «. Dalje »sreski načelnik« piše: »U crkvi su pevali i 'Oj Hrvati', 'Lepa naša' i padali su poklici kao pred crkvom. Kad je misa završila, narodni poslanik Ivan Robić pozvao je narod da se mirno raziđe, što je mnoštvo i napravilo. ${ }^{48}$

Komandir petrinjske žandarmerijske stanice, koji je sam bio nazočan, izvijestio je da je u Novom Čiču 4. ožujka bila misa zadušnica za poginule seljake u Sibinju. Obred je bio bez govora, »sem što su seljaci otpevali pesmu 'Lepa naša domovina' i 'Kraljice Hrvata'《. Pri izlasku seljaci su klicali: »Slava sibinjskim žrtvama «, »Slava hrvatskim borcima i mučenicima «, »Slava Stjepanu Radiću, »Živio dr. Maček «, »Živila Hrvatska «, »Živio hrvatski narod «. Ondje su se, kao što vidimo, čuli mnogi poklici koje su vlasti kažnjavale i otpjevane su »plemenske pjesme «, koje su označavane kao »izazivanje plemenske netrpeljivosti«, ali u tom izvješću nemamo registrirano što se dogodilo $s$ onima koji su pjevali i klicali zabranjene pjesme i poklike. Koliko su vlasti pokazivale revnost u obavljanju posla, pokazuje i izvješće »sreskog načelnika « o tom događaju u Novom Čiču. Pred crkvom se klicalo $\gg$ Živio dr. Maček «, »Slava sibinjskim žrtvama i borcima «, »Živio hrvatski narod «, »Slava Radiću «. »Među tim poklicima pao je i poklik 'Dole', ali izaslanik ovog sreskog načelstva, koji je od crkve bio udaljen oko 200 koraka nije mogao razabrati za koga se je vikalo dole. Ostala poverljiva lica koja su se nalazila u masi, ne očekujući da će se od glavne mase tko odvojiti i ostati pred crkvom, ušla su već ranije u crkvu, tako da iskazuju da od pevanja u crkvi nisu mogla da razaberu poklike ispred crkve... ovo načelstvo preduzelo je korake da se ova stvar ispita «, kaže u svojoj revnosti načelnik čije je ime nečitko. U crkvi se »pored crkvenog obreda pevalo 'Lepa naša' i 'Kraljice Hrvata', a osim toga klicalo se je u crkvi 'Slava Sibinjskim žrtvama' «. Narod se poslije u miru razišao. Kotarski načelnik u Samoboru izvješćuje da je na misi bilo 600 ljudi. »Prigodom same mise pao je u crkvi poklik 'Živio dr. Maček!'《 Pri kraju zapjevana je u crkvi i »plemenska himna 'Lijepa naša' «, a pred crkvom su se čuli sporadični poklici »Živio dr. Maček, Živila slobodna Hrvatska, Dole krvnici«. Načelnik u izvješću obećava da će one koji su »krivi za spomenute povike uhapsiti i protivu njih po zakonu postupiti $\ll{ }^{49} \mathrm{U}$ svom opširnijem dopisu

${ }^{48}$ SBODZ, fond br. 145, k 139, inv. br. 8656/35., 8./III.1935. sreski načelnik u Velikoj Gorici telefonski izveštava sledeće.

${ }^{49}$ SBODZ, fond br. 145, k 139, Samobor 25. februara 1935.: Predmet: Samobor, zadušnice za pale u Brodskom srezu. 
ističe kako je molio župnika da zamoli vjernike da se odmah raziđu, ali da ovaj to nije učinio. »Tek kad je iz sakristije čuo da mu se u crkvi viče ‘Živio dr. Maček' izletio je pred vrata sakristije i rekao da ovo nije mjesto za manifestacije, što ga je rijetko tko i čuo.«Vjernici skupljeni na zadušnici bili su »po jednom Radićevcu na izlazu iz crkve na trgu fotografisani «, ali je vlasniku zaplijenjen aparat. »Sreski načelnik « ističe dalje: »...kolovođe samih Radićevaca, jer se do sada nije ustanovilo tko je vikao spomenute nedozvoljene poklike, biće povučeni na odgovornost i eksemplarno kažnjeni. «U samoj crkvi ljudi su zapjevali »Lijepa naša domovina «, »iza toga se u samoj crkvi uzviknulo 'Slava sibinjskim mučenicima', i ‘Živio dr. Maček' «. Pred crkvom se pjevala pjesma $\gg$ Oj Hrvati jošte živi $\ll$, a uzviknulo se $\mathrm{i} \gg$ Živila slobodna Hrvatska «, $\gg$ Živio dr Maček «, »Slava hrvatskim žrtvama «, »Slava Stjepanu Radiću «, »Dolje krvnici«. Nakon intervencije predstavnika kotarske vlasti ljudi su se razišli. U izvješću stoji da je sve skupa trajalo desetak minuta. ${ }^{50}$

U svojem izvješću o zadušnici u Samoboru komandir zagrebačke žandarske čete kaže kako je zadušnica imala »demonstrativni karakter«. Bilo je na njoj 500 ljudi. Okupljene je na izlazu pred crkvom slikao fotograf iz Samobora Levin Fresl. Potom su nazočni otišli na trg, zadržali se desetak minuta i klicali: »Živio Maček «, »Živila Hrvatska «, $\gg$ Slava Radiću $\ll, ~ \gg$ Slava hrvatskim mučenicima $\ll$, otpjevali su $\gg$ Hrvatsku himnu « $\mathrm{i} \gg \mathrm{Oj}$ Hrvati jošte živi $\ll$. Žandarski čelni čovjek ističe da je »jedan put viknuto 'Živila slobodna Hrvatska', 'dolje krvava vlada, dolje ubice!'« Za vrijeme zadušnice u Samoboru sve trgovine bile su zatvorene $\gg$ na poticaj nekoliko separatista $\ll$. Ističe također da je fotograf Fresl bio priveden kotarskom načelniku, gdje mu je snimljena ploča oduzeta. Oni koji su išli agitirati da radnje budu zatvorene uhićeni su. $\gg$ Sreski načelnik« dr. Mihalić ističe da nije bilo zastava »osim jedne male crne na Starom gradu,... a nije bilo ni kakvih letaka «. »Kako je masa bila po jednom Radićevcu na izlazu iz crkve na trgu fotografisana ${ }^{51}$ vlasniku je zaplenjen aparat...« »Sreski načelnik « posebno ističe kako je na Starom gradu netko stavio crnu zastavu, ali u izvješću 27. veljače ističe da je »odnosna zastavica na starom gradu u Samoboru danas rano jutro pomoću žandarmerije i jednog privatnog lica skinuta $\ll .{ }^{52}$ Komanda žandarmerije u Zagrebu podnijela je izvješće Ministarstvu unutarnjih poslova u Beogradu da je jedna skupina od 100 seljaka i seljakinja iz sela Velika Mlaka bila u mjestu Odri na zadušnici »za poginule seljake-buntovnike kod Slavonskog Broda $\ll$ i da je jedan od njih nosio »hrvatsku zastavu dugu $50 \mathrm{~cm} \ll$.

${ }^{50}$ SBODZ, fond br. 145, k 139, inv. br. 8656/35., Samobor 25. februara 1935. Br. 304 Pov/35. Predmet: Zadušnice za pale u Brodskom srezu.

${ }^{51}$ Dopis je pisan pisaćim strojem. Najprije je napisano $\gg$ fotografirana $\ll$, pa je $r$ prepravljeno rukom $u$ $s, \gg$ fotografisana $\ll$.

${ }^{52}$ SBODZ, fond br. 145, k 139, inv. br. 8656, Samobor 27. februara 1935.: Predmet: Samobor, zadušnice za pale u brodskom srezu. 
Tu informaciju javio mu je kotarski načelnik iz Velike Gorice, koji ga je molio »da se izašalje jedna patrola koja će imati ustanoviti ime onog lica, koje nosi hrvatsku zastavu radi uzimanja istog na zakonsku odgovornost $\ll$. Žandarmerijski čelnik odmah je poslao patrolu u Veliku Mlaku, ali su seljaci već stigli $\gg$ prekim putem $\ll u$ svoje selo pa se nije moglo otkriti tko je nosio zastavu. Iz Ministarstva taj događaj nisu htjeli samo tako $\gg$ prepustiti zaboravu $\ll$, pa je poslan dopis banskoj upravi u Zagrebu: »Ministarstvu je čast dostaviti prednje Kraljevskoj banskoj upravi s molbom za izveštaj. ${ }^{53} \mathrm{Nije}$ sačuvana dokumentacija o tome je li otkriven i pozvan $\gg$ na zakonsku odgovornost « onaj tko je nosio hrvatsku zastavu dugačku $50 \mathrm{~cm}$.

Iako je biskup Antun Akšamović zabranio mise zadušnice u svojoj biskupiji, ipak su one održane na dvama mjestima: u Donjim Andrijevcima i Vinkovcima. Komandir slavonskobrodske žandarske čete izvješćuje u jednom dopisu Kraljevsku bansku upravu u Zagrebu da je 28. veljače održana zadušnica u Donjim Andrijevcima za »poginule seljake-buntovnike «. Zadušnici je nazočilo stotinu ljudi »koji kad su napustili crkvu pokazivali su na licima negodovanje protivu državne vlasti «, postavlja psihološku dijagnozu glavni brodski policajac. U svom dopisu on optužuje župnika Mirkovića ${ }^{54}$ koji je opravdavao svoju odluku time što je ubijen na gradskom groblju njegov rođak Ivan Borevković, no predstojnik policije misli da je to laž jer ne bi došlo stotinu seljaka. »Izgleda da je župnik Mirković pošao stopama svoga prečasnika župnika Gerstnera i da je potpuno pao pod uticaj amošnjih seljaka koji su poznati kao ogorčeni separatisti frankovci «, tvrdio je policijski predstojnik iz Broda. Protiv župnika podignuta je prijava kod nadležnih vlasti. Očito je ta zadušnica u Andrijevcima bila vrlo uznemiravajuća kada je sam ministar unutarnjih poslova tražio od Kraljevske banske uprave u Zagrebu izvješće o njoj. ${ }^{55}$

\section{Zaključak}

U radu se predstavljaju pogledi nadbiskupa Alojzija Stepinca na krizu koju je izazvao zločin što su ga na početku predizborne kampanje u veljači 1935. godine nad hrvatskim seljacima u Sibinju i na gradskom groblju u Brodu počinili jugoslaven-

${ }^{53}$ SBODZ, fond br. 145, k 139, inv. br. 8656/35, Savski žandarmeriski puk Pov. Br. 583, 1. marta 1935.; Ministarstvo unutrašnjih poslova Odeljenje za državnu zaštitu Pov. II br. 10826, 7. marta 1935., Predmet: Održavanje zadušnica za poginule seljake buntovnike kod Slav. Broda u mestu Odri.

${ }^{54}$ Josip Mirković, jedan od osam svećenika brodskoga kraja kojega su ubile komunističke vlasti poslije Drugoga svjetskoga rata.

${ }^{55}$ SBODZ, fond br. 145, k 139, inv. br. 8656, Ministarstvo unutrašnjih poslova Odeljenje za državnu zaštitu Pov. II, 11. marta 1935.: Predmet: Održavanje zadušnica u Andrijevcima za poginule seljake buntovnike u Sibinju i Slav. Brodu; Savski žandarmeriski puk, Pov. Br. 620., 4. marta 1935. Opravdanje zadušnica u Andrijevcima za poginule seljake buntovnike u Sibinju i Slavonskom Brodu. 
ski žandari, potaknuti pripadnicima četničke organizacije. Iako su svi mjerodavni nositelji vlasti optuživali seljake za pokolj koji su sami doživjeli, i osobito župnika iz Podcrkavlja Mihovila Praskića, nadbiskup Stepinac jasno je označio bitni uzrok svega: neravnopravnost naroda i samovolja žandara. Na taj duboki korijen uzroka upozoravao je vlasti, bana Kostrenčića, a preko njega i vladu. »Međutim vlada neće o tome ni čuti «, zapisao je u svome dnevniku. Mladi je nadbiskup dopustio služenje mise zadušnice za poginule seljake u zagrebačkoj katedrali, gdje je bilo nazočno šest do sedam tisuća ljudi. I u drugim dijelovima Zagrebačke nadbiskupije spontano su služene mise zadušnice. Ban je to pokušao spriječiti pozivajući se i na to da je mise zabranio biskup Akšamović, na čijem se teritoriju zločin dogodio. Stepinac mu je jasno dao do znanja da su »ovdje druge prilike«. Zadušnice su prošle bez većih incidenata i policijske intervencije, ali su i pjesme i poklici koji su ih pratili (»živila slobodna Hrvatska «, »dolje krvavi režim «, »dole Beograd «, »dolje Srbija «, $\gg \check{Z} i-$ vio hrvatski narod $\ll$, $\gg$ slava Stjepanu Radiću $\ll$, $\gg$ slava Sibinjskim žrtvama $\ll$ ), zbog kojih su seljaci bili osuđeni na novčane i zatvorske kazne, jasno pokazivali temeljno raspoloženje naroda koji je želio svoju samostalnu državu. Nekažnjeni sibinjski zločin nad hrvatskim seljacima i komemoracija žrtava toga zločina upisali su se u sjećanje hrvatskoga naroda. Sasvim je sigurno da je i zbog toga narod samo nepunih šest godina kasnije s oduševljenjem pozdravio stvaranje nove, samostalne države.

Nadbiskup Stepinac bio je čvrsto uvjeren da je uzrok prosvjeda seljaka i njihove pobune u selima brodskoga kotara daleko dublji od onoga koji su željele vidjeti vlasti monarhističke Jugoslavije. Iako sam nije poticao održavanje misa zadušnica za sibinjske žrtve, nadbiskup Stepinac ih je odobrio, što je bila tada izuzetno hrabra odluka, koja mu je priskrbila teške osude nositelja vlasti. To je samo jedan od primjera kojim je mladi nadbiskup pokazao da je on osobno, a preko njega i Katolička Crkva u obrani hrvatske nacionalne svijesti vrlo važan stup hrvatskoga naroda, njegova nacionalnoga i vjerskoga identiteta. Crkva je u tom delikatnom trenutku, kao i cijelo to vrijeme monarhističko fašističke diktature, stajala u oporbi prema unitarističkom velikosrpskom režimu i time, uz vodeću hrvatsku oporbenu stranku na čelu s dr. Vladkom Mačekom, bila presudan čimbenik u borbi za slobodu i nacionalni i vjerski identitet hrvatskoga naroda.

Važno je istaknuti da je jezik dokumenata, kojim vode prepisku nositelji vlasti, najčešće srpski, rijetko na ćirilici. Dopisi predstavnika policije i žandara uvijek su na srpskom jeziku i ćirilici. To je još jedan dokaz ravnopravnosti u državi koja je ratovala protiv radnoga, mirnoga temelja svake države: seljaka. Takva je država nužno morala propasti. 


\title{
ARCHBISHOP STEPINAC ON THE VICTIMS FROM SIBINJ AND MEMORIAL MASSES FOR THEM IN THE CHURCHES OF THE ZAGREB ARCHDIOCESE IN FEBRUARY AND MARCH OF 1935
}

\author{
Mato ARTUKOVIĆ*
}

Summary: The paper presents the views of Archbishop Alojzije Stepinac on the victims from Sibinj during the 1935 election campaign. For the events in which 15 Croatian peasants were killed the authorities accused the peasants themselves and the pastor from Podcrkavlje Mihovil Praskić. Archbishop Stepinac had clearly pointed out the underlying cause of everything: the inequality between peoples and the tyranny of the police. He allowed the celebration of the memorial mass service for the killed peasants, which annoyed the authorities. Inspired by the example of Zagreb, memorial mass services were spontaneously celebrated in other places of the Archdiocese as well, for the victims of the crime for which nobody has answered.

Keywords: the Sibinj victims 1935, Archbishop Alojzije Stepinac and the Sibinj victims, memorial mass services in Zagreb and other parishes of the Zagreb Archdiocese, songs and cries at the memorial masses.

\footnotetext{
* Mato Artuković, Ph. D., Croatian Institute of History - Section for the History of Slavonia, Syrmia and Baranya, Ante Starčevića 8, 35000 Slavonski Brod, Croatia, artukovic.mato@gmail.com
} 